\title{
Molecular profiling of chickpea mutants isolated from EMS and gamma rays treatments
}

\author{
Umavathi S. ${ }^{1 *} \cdot$ Mullainathan L. ${ }^{2}$ \\ ${ }^{1}$ Adhiyaman Arts and Science College for Women, Department of Botany, Kursampatti, Uthangarai, Krishnagiri 635207, Tamil Nadu, India \\ ${ }^{2}$ Annamalai University, Department of Botany, Annamalai Nagar, Chidambaram, Tamil Nadu 608002, India
}

\begin{abstract}
Summary: Conventional mutation breeding techniques have often been used to improve yield, disease and pest resistance in crop plants. In the present attempt, two well-known mutagenic agents ethyl methane sulphonate and EMS were employed in order to induce genetic variability variety of chick pea Co -4 obtained from Tamil Nadu Agricultural University. The seeds were treated with different concentrations of EMS (10-50 $\mathrm{mM})$ and Gamma rays (20-60 kR). A total of 369 mutants which alter the height, leaf structure, colour of flower, seed, size of pod, duration of the plant were isolated and characterized. Among them, five true breeding mutants namely Early flowering mutant (EFM), Bold pod mutant (BPM), Bold seed mutant BSM), High yielding mutant (HYM) and High protein content mutant (HPC), which directly influenced the economic value of the crop were selected for further study. The results revealed a significant positive increase in the qualitative traits among the mutant lines. The RAPD profiling of isolated mutants revealed a total of 129 bands, among them 92 were polymorphic with an average of 70.99 percentage of polymorphism. Apart from 28 bands, all the bands seemed to be mutation. The presence of new bands and absence of existing bands might be the reason for quality improvement of chickpea. The RAPD is considered as an excellent marker to differentiate mutants from their parents, to assess genetic variation and phylogenetic relationship.

Key words: chickpeas, genetic variability, mutants, mutation, polymorphism, RAPD
\end{abstract}

\section{Introduction}

Chickpea belongs to the family Fabaceae. It comprises 43 taxa, out of which 9 are annual, 33 perennial and 1 unspecified. The only cultivated species in the genus is Cicer arietinum. Chickpea holds a demanding role in India to overcome protein malnutrition where most of the population prefer vegetarian diet. Due to its ability to fix atmospheric nitrogen and low water requirements, it offers significant increases in agricultural production even in dry land. In India, chickpea constitutes around $40 \%$ of the total cropped area, but its yield do not witness much appreciation and results decrease trends in per capita availability of pulse. One of the main reasons for breakthrough in chickpea production is its narrow genetic variability. The problem of dwindling chickpea production can be unravelled from rapid enhancement in production through genetic manipulation (Ahmad et

Corresponding author

umas67@ymail.com

Cite this article:

Umavathi S. \& Mullainathan L. (2019). Molecular profiling of chickpea mutants isolated from EMS and gamma rays treatments. Ratar. Pourt., 56 (3), 88-96. al., 2014). The genetic enhancement in Chickpea can be achieved by various crop improvement strategies like selection, hybridisation, mutation, etc. Among all the adopted breeding methodologies, mutation has been considered a potent tool for the improvements as well as evolution of crops (Solanki et al., 2011).

In chickpea, both physical and chemical mutagens were used in the past to create variability and this mutagenic effect results in varietal development in this crop. So far, mutation breeding has released 34 varieties of different pulse crops (Gopalakrishna and Reddy, 2009). Therefore, the present study was focused to isolate desired mutants through mutation breeding and its molecular profiling through RAPD markers.

\section{Material and Methods}

Plant Material

Chickpea variety $\mathrm{Co}-4$ obtained from Tamil Nadu Agricultural University, Coimbatore, India, was treated with different concentrations of gamma rays and EMS. The seeds were sowed in field condition along with control to raise $\mathrm{M}_{1}$ generation. The seeds of $\mathrm{M}_{1}$ progenies were used to raise the successive generation up to $\mathrm{M}_{4}$ generation. The mutants with desired characters were selected, isolated and raised separately for further investigation. 


\section{DNA Extraction}

The DNA was extracted from small protruding leaves by CTAB method with some modification (Doyle and Doyle, 1990). DNA concentration was quantified spectrophotometrically and their quality was assessed by $1 \%$ agarose gel electrophoresis.

\section{RAPD Analysis}

PCR was run in a thermal cycler with $25 \mathrm{ng}$ DNA as a template. All amplified products were electrophoresed on $1.2 \%$ agarose gel. The fingerprints were examined under the UV transilluminator and photographed using gel documentation system.

\section{Results and Discussion}

Screening and isolation of high yielding mutants

The details of the mutants screened and isolated from both gamma rays and $\mathrm{EMSO}$ in $\mathrm{M}_{4}$ generations are given in Tables $1 \& 2$. The early flowering mutant, bold pod mutant, bold seed mutant, high yielding mutant and high protein content mutant were considered to be more desirable characters. Such mutants were distinctly much superior to the others were screened from $\mathrm{M}_{3}$ generation and grown in $\mathrm{M}_{4}$ generation are discussed below.

\section{Early flowering mutants}

The early flowering mutants were isolated from 30 $\mathrm{mM}$ in EMS treatments. The number of days to first flowering was reduced up to five days compared to control. These mutants were characterized by a significant increase in plant height, number of pods per plant, yield per plant and hundred seed weight over control. One of the prime goals of breeding is to reduce the duration of crops. The early flowering mutants showed reduced number of days to first flowering and 50\% flowering resulted in early maturity, and finally reduced the duration of the crops. The maturity of the plant was reduced by about 5-7 days earlier in such mutants.

\section{Bold pod mutant}

Bold pod mutant can be considered a useful variation because it directly influences the economic value of chickpea. Such bold pod mutants exhibited vigorous growth and large seeded pods. Consequently, the results were increased number of seeds per pod, yield per plant, hundred seed weight and relatively higher percentage of protein content. These mutants were isolated from $30 \mathrm{mM}$ of EMS.

\section{Bold seed mutant}

The bold seeded mutants had significantly increased yield per plant and hundred seed weight over other mutants and control. These mutants were isolated from $40 \mathrm{kR}$ of gamma rays and were characterized by an increased number of primary branches per plant, number of secondary branches per plant and number of pods per plant with a significant level of protein content over control. The number of pods was fewer when compared to other mutants, but the hundred seed weight was high due to large sized seeds.

Table 1. Brief description of the mutants isolated in $\mathrm{M}_{4}$ generation of Chick pea

\begin{tabular}{lcc}
\hline Mutant & Treatment & Dose/Conc. \\
\hline Early flowering Mutant & EMS & $30 \mathrm{mM}$ \\
Bold pod mutant & EMS & $30 \mathrm{mM}$ \\
Bold seed mutant & Gamma rays & $40 \mathrm{kR}$ \\
High yielding mutant & EMS/Gamma rays & $30 \mathrm{mM} / 40 \mathrm{kR}$ \\
Protein content mutant & EMS & $30 \mathrm{mM}$ \\
\hline
\end{tabular}

Table 2. Estimates of the quantitative traits of the mutants isolated from $\mathrm{M}_{4}$ generation of chickpea

\begin{tabular}{|c|c|c|c|c|c|c|c|c|c|c|}
\hline Mutants & $\begin{array}{l}\text { Plant } \\
\text { height }\end{array}$ & $\begin{array}{c}\text { Primary } \\
\text { branches }\end{array}$ & $\begin{array}{l}\text { Secondary } \\
\text { branches }\end{array}$ & $\begin{array}{c}\text { First } \\
\text { flowering }\end{array}$ & $\begin{array}{c}50 \% \\
\text { flowering }\end{array}$ & $\begin{array}{l}\text { Number } \\
\text { of pods }\end{array}$ & $\begin{array}{c}\text { Seeds } \\
\text { per } \\
\text { pod }\end{array}$ & Yield & $\begin{array}{c}100 \text { seed } \\
\text { weight }\end{array}$ & $\begin{array}{l}\text { Protein } \\
\text { content }\end{array}$ \\
\hline Control & 39.80 & 3 & 7 & 35 & 50 & 48 & $1-2$ & 12.74 & 30.01 & 21.34 \\
\hline $\begin{array}{l}\text { Early } \\
\text { flowering }\end{array}$ & 41.40 & 8 & 13 & 30 & 45 & 50 & $1-2$ & 12.08 & 28.26 & 20.78 \\
\hline $\begin{array}{l}\text { Bold pod } \\
\text { mutant }\end{array}$ & 40.01 & 10 & 19 & 32 & 42 & 55 & $1-2$ & 19.10 & 34.58 & 21.98 \\
\hline $\begin{array}{l}\text { Bold seed } \\
\text { mutants }\end{array}$ & 40.12 & 9 & 18 & 32 & 42 & 49 & $1-2$ & 16.29 & 33.67 & 21.23 \\
\hline $\begin{array}{l}\text { High } \\
\text { yielding } \\
\text { mutant }\end{array}$ & 40.16 & 12 & 24 & 31 & 40 & 62 & $1-2$ & 18.23 & 33.16 & 22.03 \\
\hline $\begin{array}{l}\text { High protein } \\
\text { content }\end{array}$ & 38.44 & 8 & 16 & 33 & 42 & 49 & $1-2$ & 12.98 & 29.87 & 22.56 \\
\hline
\end{tabular}


Table 3. Analysis of RAPD banding pattern for Chick pea mutants isolated from $\mathrm{M}_{4}$ generation

\begin{tabular}{|c|c|c|c|c|c|}
\hline S. No & Primer code & Total no. of bands & Polymorphic bands & Monomorphic bands & $\%$ of polymorphism \\
\hline 1 & OPA - 01 & 11 & 8 & 3 & 72.73 \\
\hline 2 & OPA - 02 & 18 & 12 & 6 & 66.67 \\
\hline 3 & OPA - 03 & 8 & 4 & 4 & 50.00 \\
\hline 4 & OPA - 04 & 20 & 15 & 5 & 75.00 \\
\hline 5 & $0 \mathrm{PA}-05$ & 17 & 12 & 5 & 70.58 \\
\hline 6 & OPA - 06 & 9 & 7 & 2 & 77.78 \\
\hline 7 & OPA - 07 & 9 & 8 & 1 & 88.89 \\
\hline 8 & OPA - 08 & 15 & 11 & 4 & 73.34 \\
\hline 9 & OPA - 09 & 12 & 9 & 3 & 75.00 \\
\hline \multirow[t]{3}{*}{10} & OPA - 10 & 10 & 6 & 4 & 60.00 \\
\hline & Total & 129 & 92 & 37 & 709.99 \\
\hline & Average & 12.9 & 9.2 & 3.7 & 70.99 \\
\hline
\end{tabular}

\section{High yielding mutant}

These mutants were isolated from $30 \mathrm{mM}$ in EMS and $40 \mathrm{kR}$ in gamma rays treatments. These mutants were characterized by the highest number of primary branches per plant, secondary branches per plant with an increased number of pods per plant, yield per plant, hundred seed weight and protein percentage. High yielding mutants directly influence the economic value because of direct association with the yield.

\section{High protein content}

These mutants were isolated from $30 \mathrm{mM}$ in EMS and $40 \mathrm{kR}$ in gamma rays treatment. These mutants possess a moderate level of increase in the number of pods per plants, yield per plant and hundred seed weight with high percentage of protein content over other mutants and control.

Five chickpea mutants along with the control were subjected to RAPD analysis using ten primers for identifying DNA polymorphism. All the primers revealed a high DNA polymorphism among the mutant population like early flowering mutant, bold pod mutant, bold seed mutant, high yielding mutant and high protein content mutant. All the primers were responded for amplification (Table 3) and amplified a total of 129 RAPD bands ranging from 1500 bp to100 bp (Plates 1-3). Out of these 129 bands, 92 bands were polymorphic with an average of $70.99 \%$ polymorphism. Among the 92 amplified bands, 28 bands were universally present and the remaining bands were varied for their amplification between the mutants as well as control.

RAPD bands appeared as new bands in specific mutagen induced mutants, while some of the RAPD bands were present in the control and disappeared in some specific mutants. The main changes observed in RAPD profiles were both in the presence or absence of different bands with variations of their intensities.
Among the ten primers, 4 primers (OPA -07, OPA-06, OPA -04 and OPA-09) showed highest polymorphism, while the other primers gave the moderate polymorphism.

Genetic distances between the mutants and control plants were estimated based on Jaccard's similarity coefficient matrix. The Jaccard's coefficient similarity varied from 0.545 to 0.727 (Table 4). These results indicated that a moderate to a high extent of genetic polymorphism was observed between the control plant and the mutants used for the analysis. Dendrogram analysis using UPGMA method exhibited clustering of all the mutants and the control plant into two major clusters; one comparing control and bold pod mutants, and the other cluster consisting of early flowering mutant, bold seed mutant, high yielding mutant and high protein content (Fig. 1).

Plant improvement through molecular markers has been used for estimating genetic diversity until recently. Many better molecular techniques are developed these days for analysing genetic variance and diversity when compared to earlier molecular techniques (Bhat et al., 2011). Random amplified polymorphic DNA analysis is widely used for genotyping, genetic mapping, molecular selection, polygenic and taxonomic studies (Yuzbasioglu et al., 2006). RAPD analysis can also be applicable for the detection of DNA alterations caused as a result of genotoxical agent (Atienzar et al., 2002).

Among the other molecular methods the RAPD analysis has considerable advantages because it is a fast, less expensive and applicable to any plants without prior information about nucleotide sequence and in the potential detection of DNA damage through mutation, etc. (Ahloowalia and Maluszynksi, 2001). The RAPD analysis is used to identify the DNA polymorphism induced by mutagens in Baby's breath (Khawale et al., 2007), Sunflower (Erdem and Oldacay, 2004) and Cypress (Ishii et al., 2003). 
Table 4. Similarity matrix based on Jaccard coefficient of five mutants and control

\begin{tabular}{ccccccc}
\hline & Control & EFM & BPM & BSM & HYM & HPC \\
\hline Control & 1 & 0.545 & 0.619 & 0.522 & 0.682 & 0.591 \\
EFM & & 1 & 0.478 & 0.667 & 0.762 & 0.750 \\
BPM & & & 1 & 0.458 & 0.458 & 0.652 \\
BSM & & & & & 1 & 0.714 \\
HYM & & & & & 0.727 \\
HPC & & & & & 1 \\
\hline
\end{tabular}

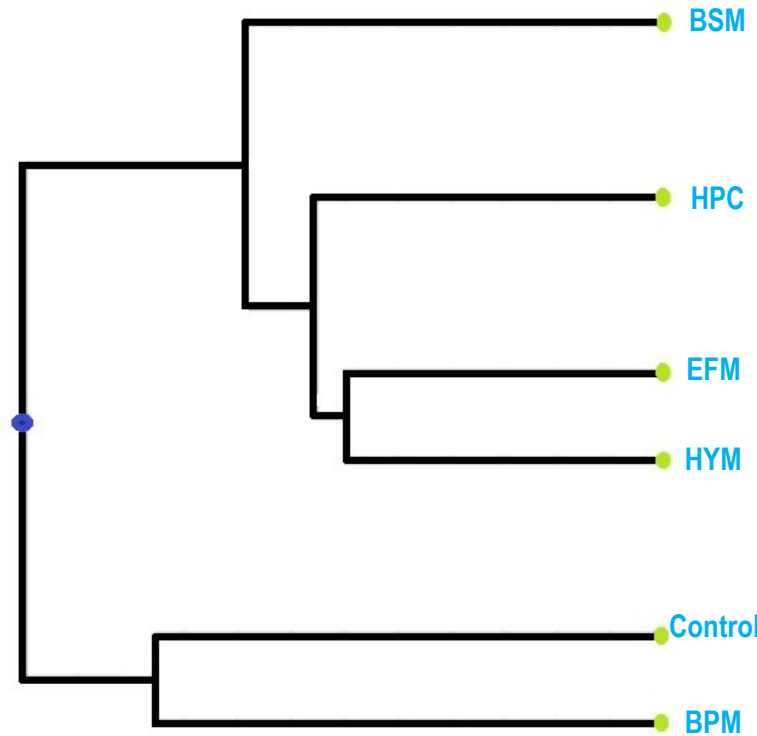

Figure 1. Dendrogram analysis of five mutants and control

In the present study, five mutants of chickpea along with control were studied by RAPD assay for analysing and identifying DNA polymorphism. The ten random decamer primers revealed a high DNA polymorphism in each mutant. A total of 129 bands scored of which 92 bands were polymorphic with an average of 70.99 percentage polymorphism. Only four primers (OPA-07, OPA-06, OPA-04 and OPA-09) showed the highest percentage of polymorphism. Similar wide-ranging levels of polymorphism have been reported by Senthamizhselvi et al., (2008) in Amla, Encheva et al., (2005) in sunflower.

The presence or absences of RAPD bands are used to estimate diversity and in measurement of similarity (Wang et al., 2009; Choi et al., 2006). At molecular level, direct acting alkylating agents such as gamma rays and EMS, primarily cause point mutations, which are the results of a single base per deletion, addition or substitution. These changes in DNA caused by mutagens may lead to genetic variation, which can be detected by molecular marker analysis, including RAPD assay in several species (Elmeer et al., 2009; Senapati and Rout, 2008; Khawale et al., 2007).

Hegazi and Hamideldin (2010) observed the changes in the DNA bands, where the maid changes in the RAPD profiles of the appearance or disappearance of different bands with diversity in their intensity. These effects are because of the structural rearrangement in DNA caused by DNA damages through mutagenic treatment.

In view of the importance of genetic diversity, in this study, the genetic diversities among different mutants isolated through mutagenic treatments were analysed with the help of RAPD markers. The overall similarity index ranged from 0.545 to 0.727 showing the high genetic similarity as well as a narrow genetic base among the studied mutants.

The use of more primers will increase the chance of high diversity. Investigation by Lakhanpaul et al., (2000) verified highest level of genetic similarity between the 32 accessions of mung bean and they ascribed that may be due to its self-pollinating characters. The formation of only two clusters, through hierarchical cluster analysis of the RAPD data also confirmed that the presence of low diversity at the molecular level among the selected mutants in this study.

\section{References}

Ahloowalia, B.S., and M. Maluszynski (2001). Induced Mutation. A new paradigm in plant breeding. Euphytica, 118(2): 167-173.

Atienzar, F.A., P. Venier, A.N. Jha and M.H. Depledge (2002) Evaluation of the random amplified polymorphic DNA (RAPD) assay for the detection of DNA damage and mutations, Mutat. Res. Genet. Toxicol. Environ. Mutagen., 521 (12): 151-163.

Bhat, M., S. Khan, and M. I. Kozgar (2011). Studies on induced mutations in chickpea (Cicer arietinum L.) I. Responses of the mutagenic treatments in M1 biological parameters. Elect. J. Plant Breed., 2(3): 422-424.

Choi, J., M.C. Sullards and J.A. Olzmann (2006). Oxidative damage of DJ-1 is linked to sporadic Parkinson and Alzheimer diseases. $J$ Biol Chem. 281:10816-24.

Doyle, J.J., and J.L. Doyle (1990). Isolation of plant DNA from fresh tissue. Focus, 12: 13-14.

Elmeer, K.M.S., T.M.F. Gallagher and M.J. Hennerty (2009). RAPD based detection of genomic instability in cucumber plants derived from somatic embryogenesis. Afr J Biotechnol., 8 : 32193222.

Encheva, V., S.E. Gharbia, R. Wait, S. Begum and H.N. Shah (2005). Proteome analysis of serovars Typhimurium and Pullorum of Salmonella enterica subspecies I using two dimensional gel electrophoresis and LC/MS/MS. BMC Microbiol 5: 42-45.

Erdem, G., and S. Oldacay, 2004. Employment of RAPD technique to assess the genetic stability of Helianthus annuиs treated with different mutagenic agents. J. Appl. Sci., 4: 277-281.

Hegazi, A.Z., and N. Hamideldin, 2010. The effect of gamma irradiation on enhancement of growth and seed yield of okra (Abelmoschus esculentus (L.) Moench) and associated molecular changes. J. Horti \& Forestry., 2(3): 038-051. 
Ishii, K., Y. Yamada, Y. Hase, N. Shikazono and A. Tanaka, 2003. RAPD analysis of mutants obtained by ion beam irradiation to hinoki cypress shoot primordial. Nucl. Instr. and Meth. In Phys. Res., 206: 570-573

Khawale, R. N., V. Yerramilli and S. K. Singh, 2007. Molecular marker assisted of in vitro chemical mutagen induced grapevine mutants. Curr. Sci., 92: 1056-1060.

Lakhanpaul, S., S. Chadha and K.V. Bhat, 2000. Random amplified polymorphic DNA (RAPD) analysis in Indian mungbean (Vigna radiata (L) Wilczek] cultivars. Genetica., 109: 227-234.

Senapati, S.K. and G.R. Rout, 2008. In vitro mutagenesis of rose with ethyl methane sulphonate (EMS) and early selection using RAPD markers. Adv. Hortic. Sci., 22: 218-222.

Senthamizh Selvi B, V. Ponnuswami and P.S. Kavitha, 2008. Use of RAPD assay for the detection of mutation changes in amla (Emblica officinalis Gaertn). Adv. Nat. Appl. Sci., 2(3): 129-134.
Solank, Ramesh and Gill and Verma, Preeti Singh and Sarvjeet (2011). Mutation Breeding in Pulses. An overview; 85-103.

Wang, Z.Y., J.M. Lin, L. Luo and Z.F. Xu, 2009.Sensitivity of Jatropa curcas seeds to (60) $\mathrm{CO}_{\gamma}$ radiation and their medical lethal dose in radiation breeding. Nan Fang Yi Ke Da Xue Xue Bao, 29: 506-508.

Wani, M.R, Kogzar MI, Tomlekova M, Khan S, Kazi G A, Sheik S A and Ahmad P, 2014. Mutation Breeding: A novel Technique for Genetic improvement of pulse crops Particulary Chick pea (Cicier arietinum L.). In: Improvement of crops in the ERA of climatic changes, Vol. 2. Springer, New York.

Yuzbasioglu, E., S. Ozcan and L. Acik, 2006. Analysis of genetic relationships among Turkish cultivars and breeding lines of Lens culinatis Mestile using RAPD markers. Genetic Resources and Crop Evolution, 53: 507-514.

\section{Molekularna karakterizacija mutanata leblebije izolovanih iz tretmana EMS i gama zracima}

\section{Umavathi S. · Mullainathan L.}

Sažetak: U radu su korišćeni poznati mutageni agensi etil metansulfonat i EMS u cilju indukovanja genetičke varijabilnosti sorte leblebije Co-4 dobijene od Poljoprivrednog univerziteta Tamil Nadu u Indiji. Seme je tretirano različitim koncentracijama EMS (10-50 mM) i gama zracima (20-60 kR). Izolovano je i karakterisano ukupno 369 mutanata, a među njima je pet pravih oplemenjivačkih mutanata odabrano za istraživanje. Rezultati su pokazali značajno pozitivno poboljšanje kvalitativnih osobina u linijama mutanata.

Ključne reči: genetička varijabilnost, leblebija, mutacije, mutanti, polimorfizam, RAPD

PLATE 1

RAPD PROFILE - Cicer arietinum L. Var. CO-4

Gel electrophoresis showing PCR profiles of amplified DNA from control and mutants using primer OPA-04

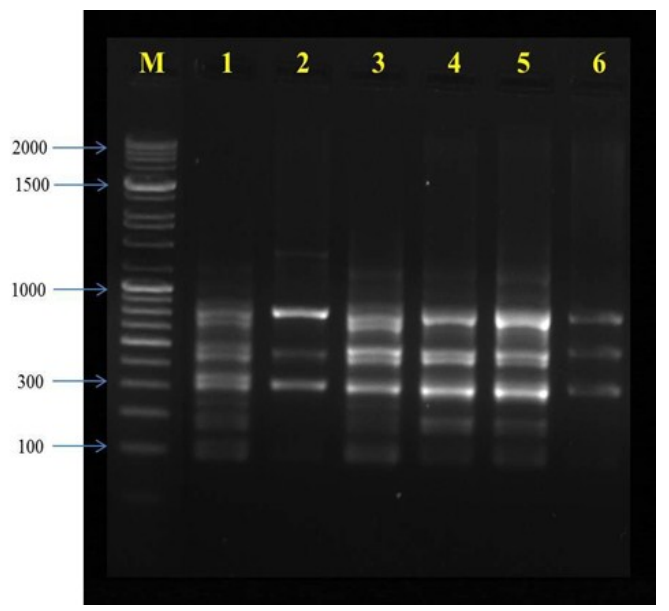

M - Marker; Lane 1 - Control; Lane 2 - Early flowering mutant; Lane 3 - Bold seed mutant; Lane 4 - Bold pod mutant; Lane 5 High yield mutant; Lane 6 - High protein mutant
Gel electrophoresis showing PCR profiles of amplified DNA from control and mutants using primer OPA-05

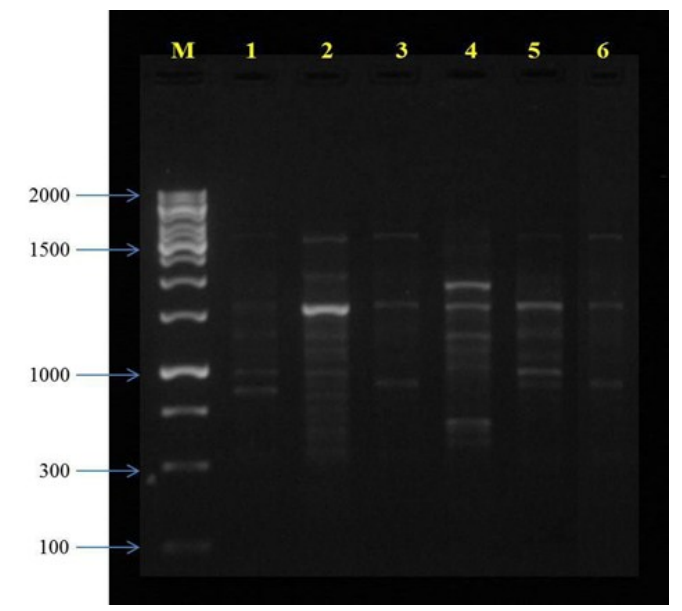

M - Marker; Lane 1 - Control; Lane 2 - Early flowering mutant; Lane 3 - Bold seed mutant; Lane 4 - Bold pod mutant; Lane 5 High yield mutant; Lane 6 - High protein mutant 


\section{PLATE 2}

\section{RAPD PROFILE - Cicer arietinum L. Var. CO-4}

Gel electrophoresis showing PCR profiles of amplified DNA from control and mutants using primer OPA-06

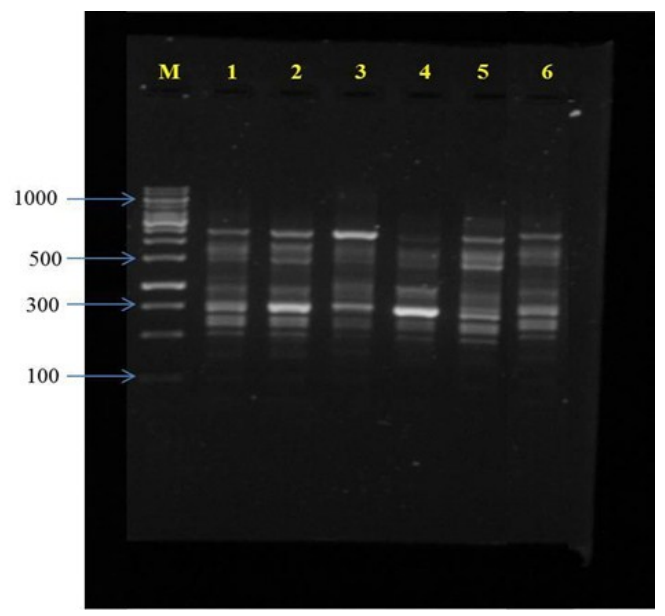

M - Marker; Lane 1 - Control; Lane 2 - Early flowering mutant; Lane 3 - Bold seed mutant; Lane 4 - Bold pod mutant; Lane 5 High yield mutant; Lane 6 - High protein mutant
Gel electrophoresis showing PCR profiles of amplified DNA from control and mutants using primer OPA-07

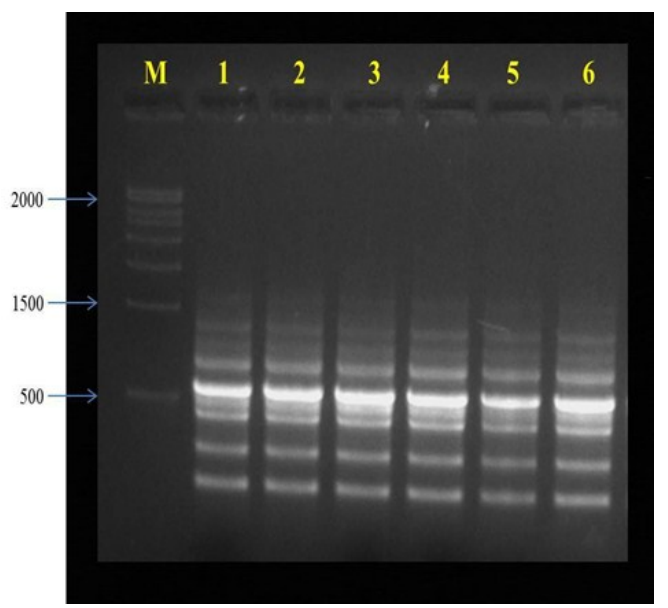

M - Marker; Lane 1 - Control; Lane 2 - Early flowering mutant; Lane 3 - Bold seed mutant; Lane 4 - Bold pod mutant; Lane 5 High yield mutant; Lane 6 - High protein mutant

\section{PLATE 3}

\section{RAPD PROFILE - Cicer arietinum L. Var. CO-4}

Gel electrophoresis showing PCR profiles of amplified DNA from control and mutants using primer OPA-08

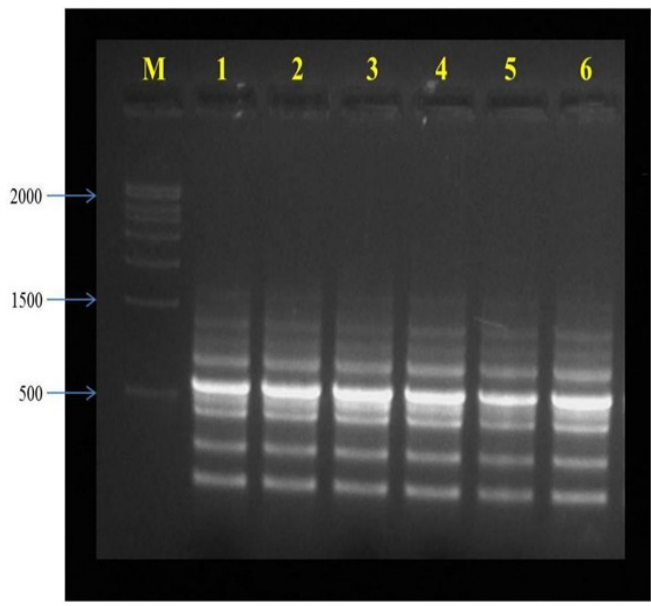

M - Marker; Lane 1 - Control; Lane 2 - Early flowering mutant; Lane 3 - Bold seed mutant; Lane 4 - Bold pod mutant; Lane 5 High yield mutant; Lane 6 - High protein mutant
Gel electrophoresis showing PCR profiles of amplified DNA from control and mutants using primer OPA-09

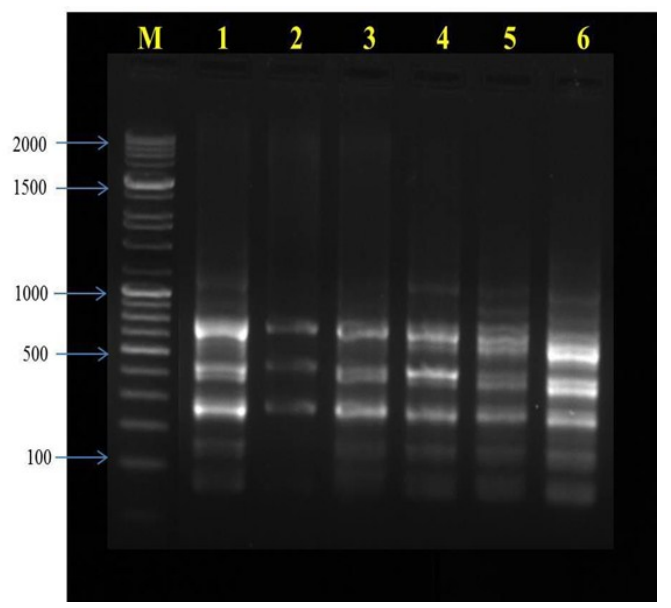

M - Marker; Lane 1 - Control; Lane 2 - Early flowering mutant Lane 3 - Bold seed mutant; Lane 4 - Bold pod mutant; Lane 5 High yield mutant; Lane 6 - High protein mutant 
S U P P L E M E N T

MORPHOLOGICAL MUTANTS

(MUTANTS WITH ALTERED LEAF MORPHOLOGY)

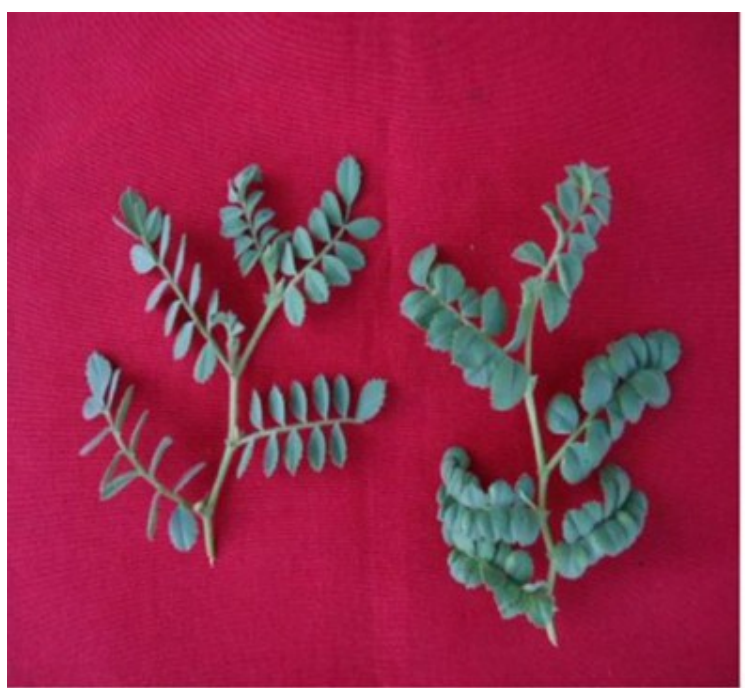

Control

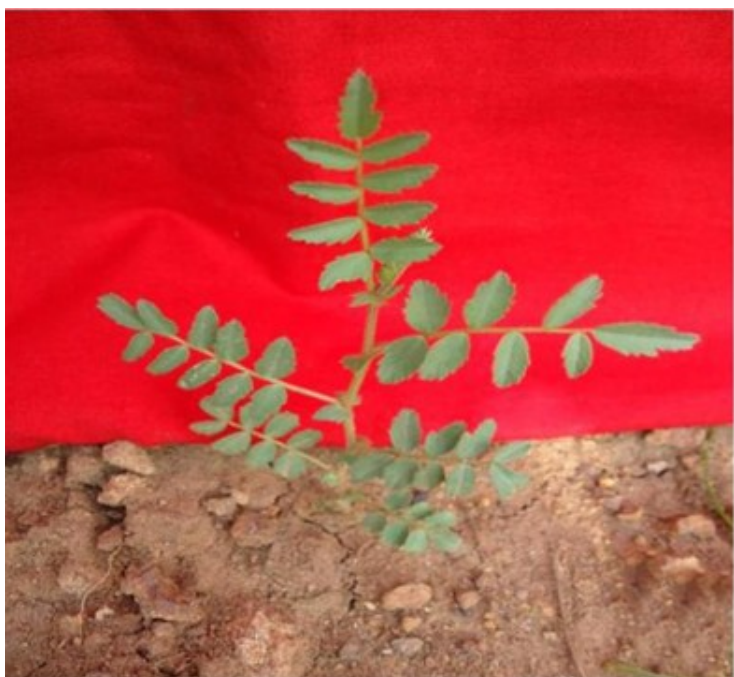

Narrow leaf $(30 \mathrm{mM})$

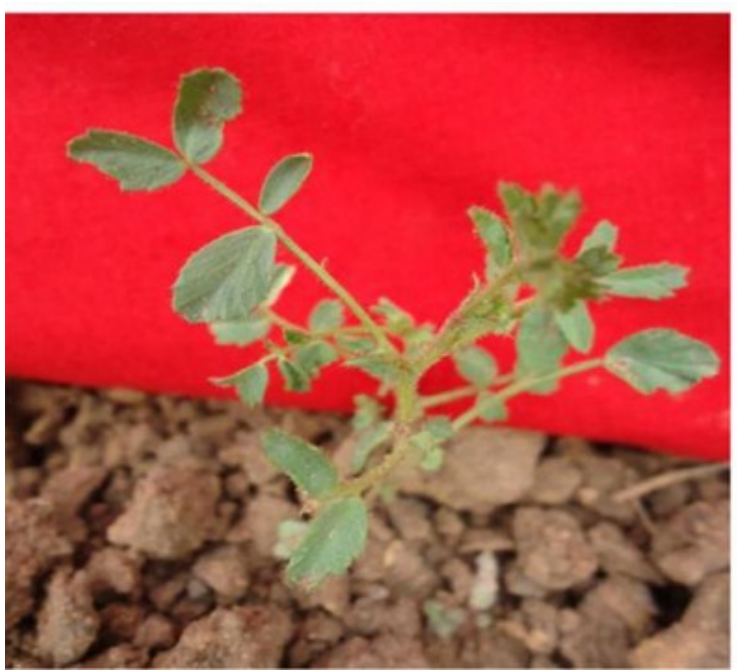

Altered leaf architecture $(40 \mathrm{mM})$

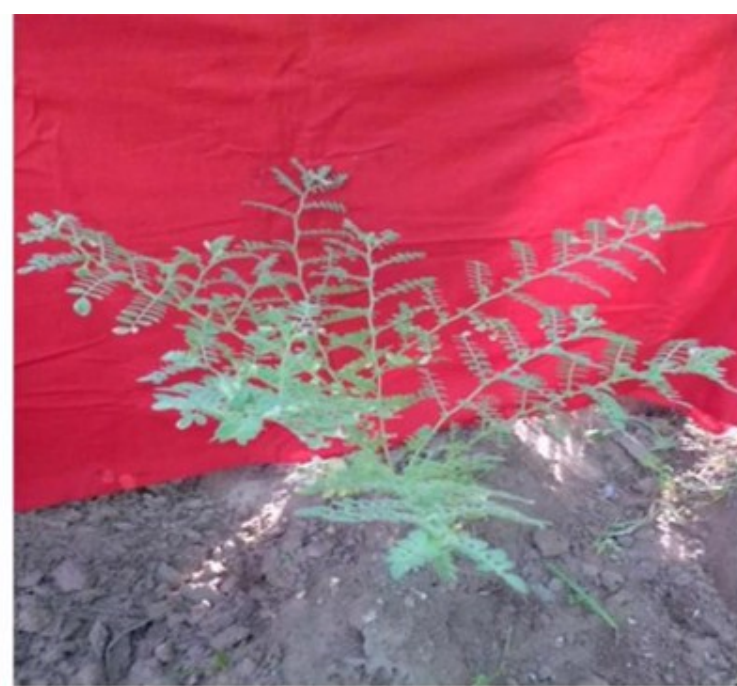

Small sized leaf (40kR)

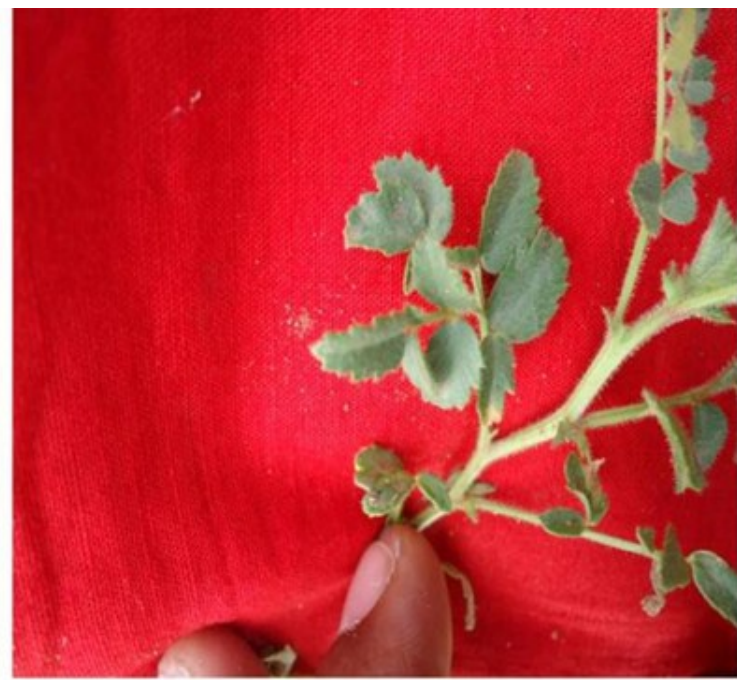

Bipinnate compound leaf $(50 \mathrm{kR})$

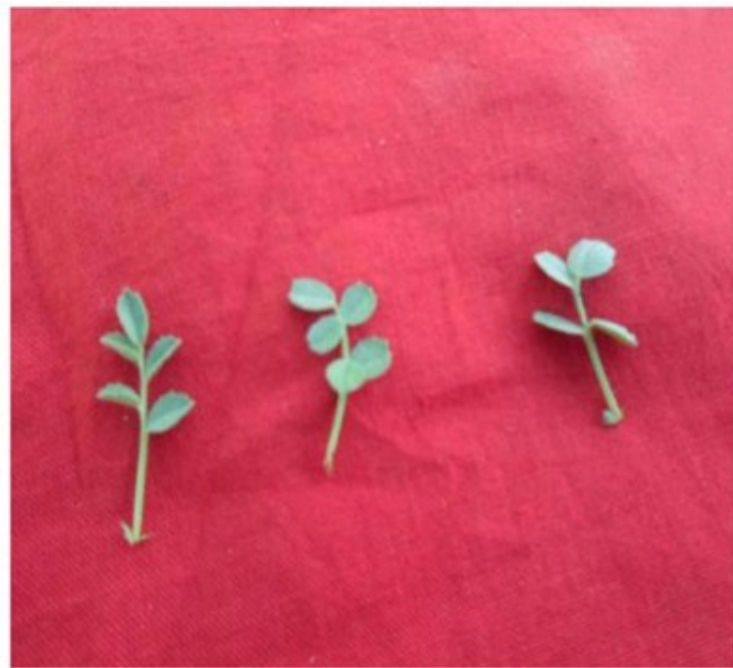

Altered leaf architecture (50kR) 
MORPHOLOGICAL MUTANTS

(MUTANTS WITH ALTERED FLOWER CHARACTERS)

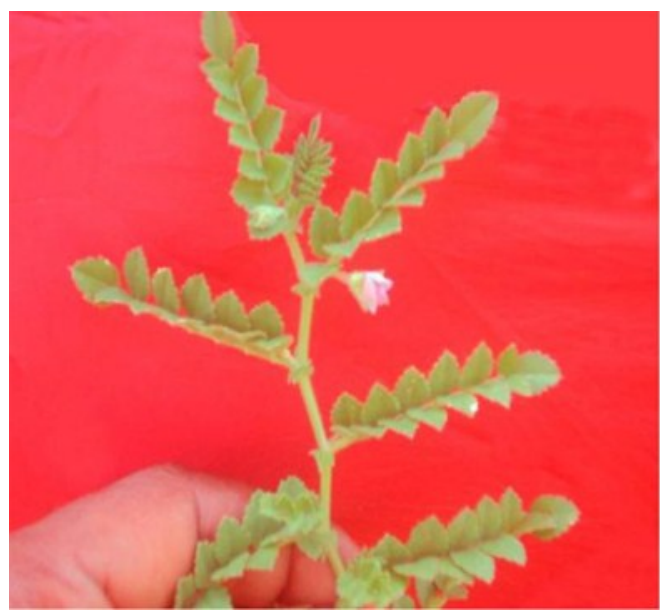

Control flower

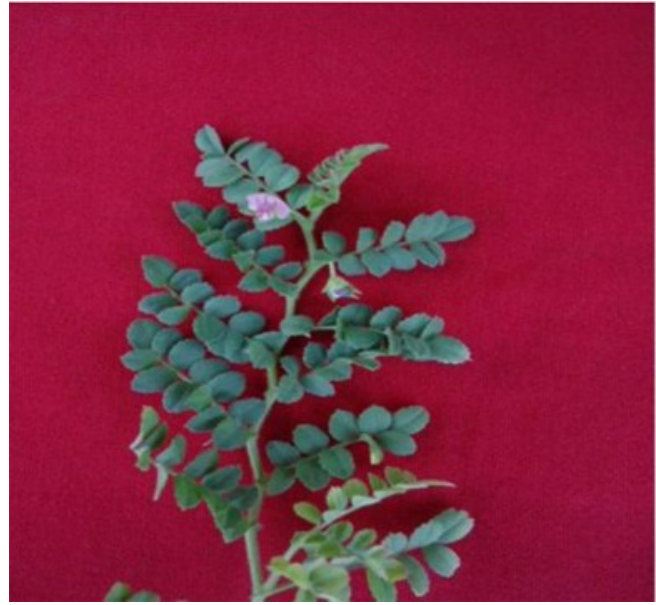

Doubled coloured flower $(30 \mathrm{mM})$

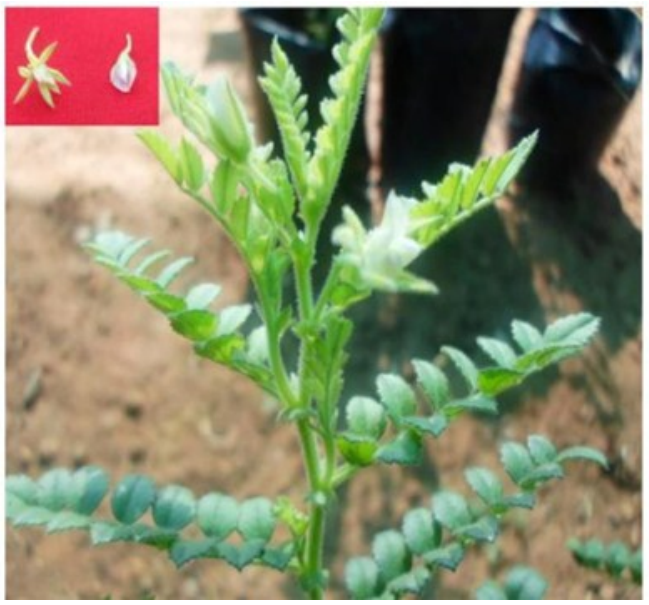

Open flower mutant $(30 \mathrm{mM})$

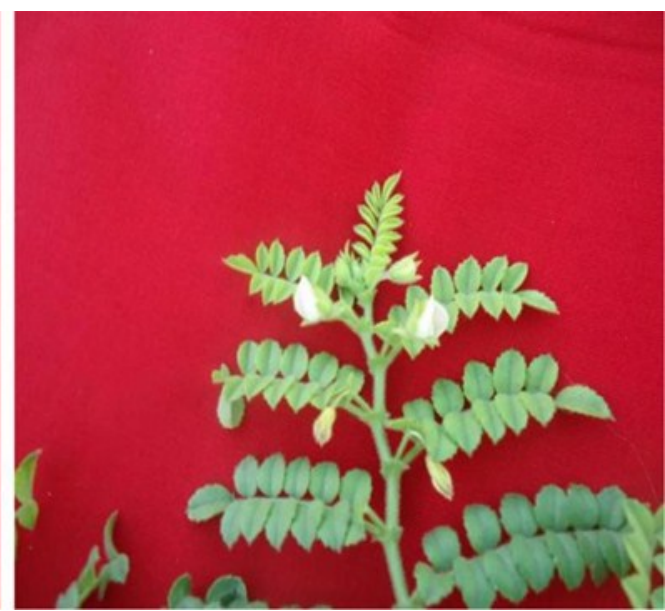

White flower $(30 \mathrm{mM})$

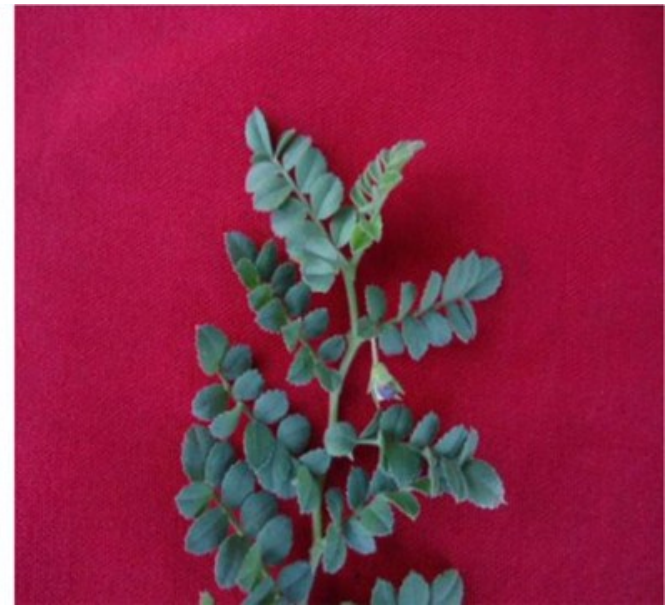

Violet flower (40kR)

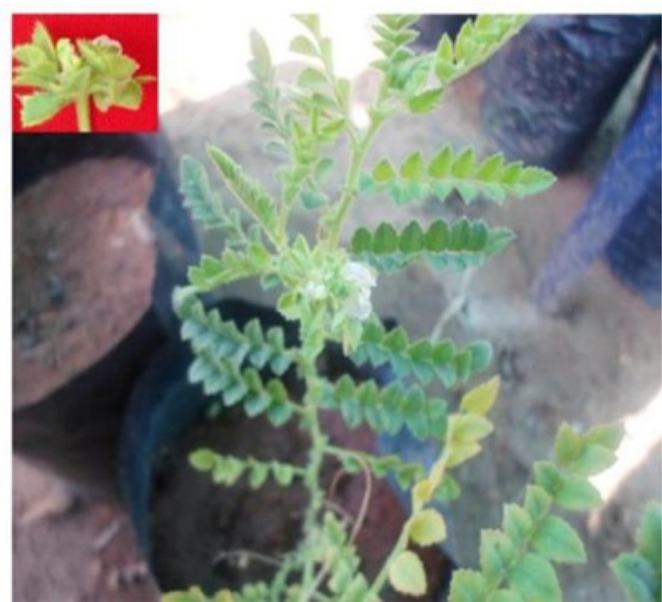

Cluster of flowers $(40 \mathrm{mM})$ 
MORPHOLOGICAL MUTANTS

(MUTANTS WITH ALTERED FLOWER ARCHITECTURE)

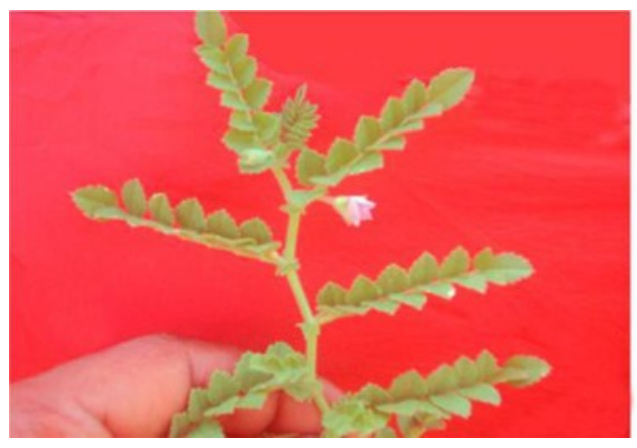

Control flower

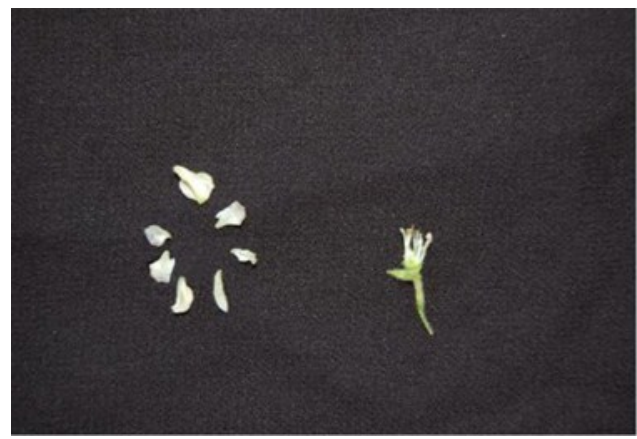

Eight petals $(30 \mathrm{kR})$

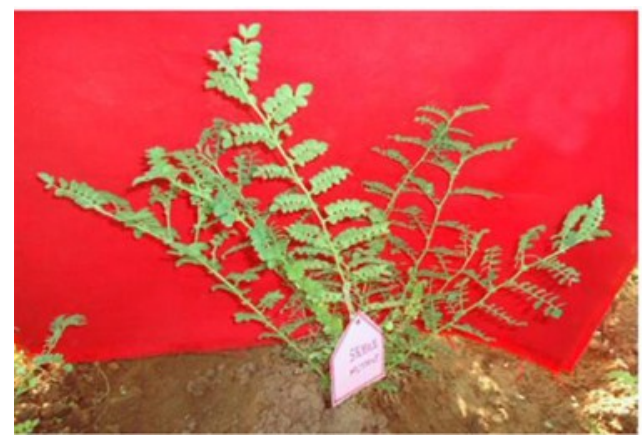

Sterile mutant (50kR)

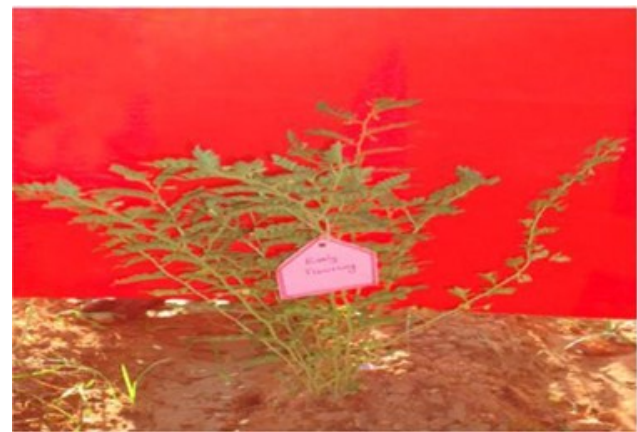

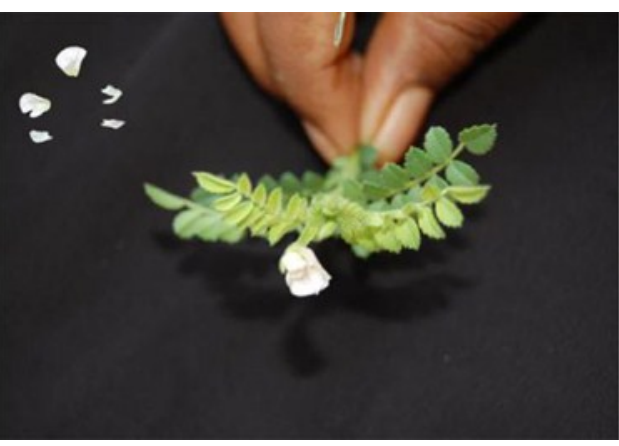

Two standard petals (40kR)

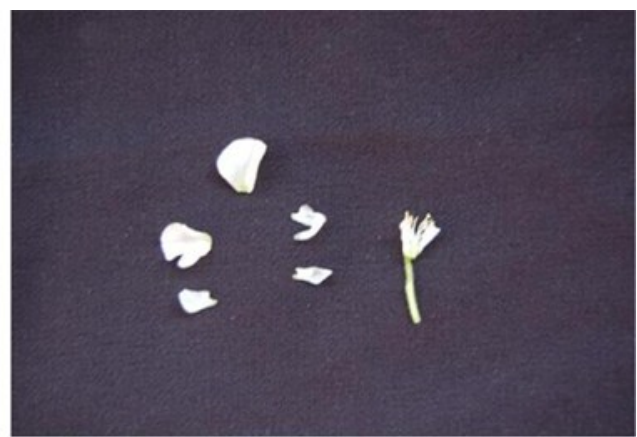

Staminode (40kR)

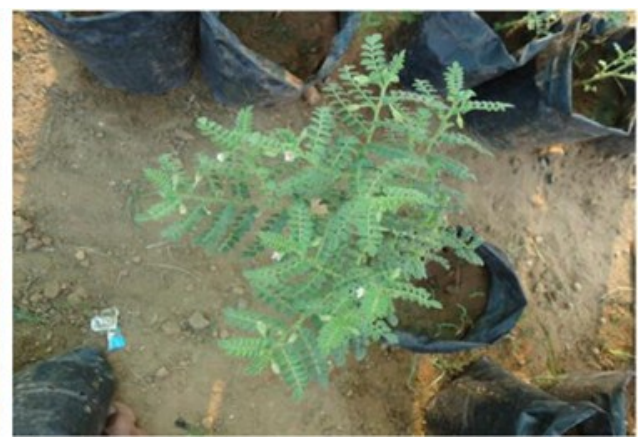

Vegetative mutant $(40 \mathrm{mM})$

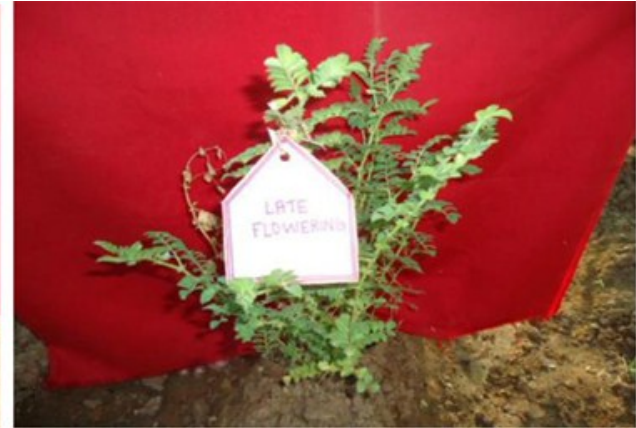

